so. The chimera of one age is often the truism of the next. Let us only call upon our friends at Edinburgh, before they separate for another year, to take this great subject into consideration, and to weigh its claims on their activity. Many a solitary teacher will be cheered, many a half-abandoned scheme will be preserved and furthered, if not by the certainty of their support, yet at any rate by the knowledge of their sympathy.

\section{THE APPROACHING TOTAL SOLAR ECLIPSE}

W $\mathrm{E}$. regret that we have, as yet, nothing very definite to announce in addition to what has been already stated with reference to the observations of the Total Solar Eclipse of the r2th of December next. We believe that an appeal is about to be made to Government, and if this be so, we may trust that anything that may be asked in the interests of Science will readily be granted by the Government. It is unfortunate that the Astronomer Royal's official position prevents his joining in the request, for his experience in connection with the large expenditure (10,000l. has already been voted) incurred by him for the approzching observation of the Transit of Venus, would be valuable in showing the necessity for the sum now required. This amounts only to a few hundreds in excess of the sum saved by the rigid economy practised by the Committee appointed to organise the arrangements connected with the late expedition.

We trust that the proposed arrangements will be brought before the British Association, in order that the influence of that important body may be made to bear upon this matter. We have recently shown the important results obtained by the late observations. It seems clear that the weather prospects for the approaching event are good, while recent calculations made by $\mathrm{Mr}$. Hind show that the totality in Ceylon is much longer than had been at first imagined, amounting to as much as $2^{\mathrm{m}}{ }_{11} \mathrm{I}^{\mathrm{s}}$ for Trincomalee, and therefore longer in the central line a few miles to the north. The accompanying map shows approximately the shadow path over India, and gives us good ground for congratulating ourselves that there are already in that country such observers as Tennant, Pogson, Herschel, Hennessy, and others, ready to occupy the best stations. The appeal made to Government includes funds for an expedition to Ceylon, under the charge of $\mathrm{Mr}$. Lockyer, who has been requested by the Royal Astronomical Society to undertake spectroscopic observations there, while M. Janssen will probably take up his station in Java. We have already stated that a strong party from Melbourne and Sydney will observe in the north of Australia. All then is in order, provided our scientific leaders will put their shoulders to the wheel.

\section{NOTES}

THE American Association for the Advancement of Science, which meets a fortnight later than our own at Indianapolis, is modelled in most respects after the pattern of the parent institution, but presents some features which the managers of our own Association may do well to take into consideration. The arranyements with regard to the opening address, sectional proceedings, \&c., are very similar, the following being the officers for the Indianopolis meeting:--President, Prof. Asa Gray, of
Cambridge ; Vice-president, Prof, George F. Barker, of New Haven; Permanent Secretary, Prof. Joseph Lovering, of Cambridge; General Secretary, Mr. F. W. Putman, of Salem; Treasurer, Mr. Wm. S. Vaux, of Philadelphia. Special convenience will be provided for microscopists in relation to the exhibition and care of any instruments or apparatus, a suite of rooms having been secured in the State House for their special use. It will be remembered that the same thing was attempted at the Liverpool meeting, but in rather a private and unacknowledged manner. Excursions are arranged to Terre Haute, a distance of seventy-three miles, including a visit to the celebrated block coal field and blast furnaces of Clay county, and to New Albany on the Ohio river, where there are a number of interesting manufactories, among them the only finishing plateglass works in the United States. Special arrangements have been made as to terms for the accommodation of the members of the Association at hotels and boarding-houses, and it is expected that all the railroads will carry the visitors at half fares.

Although the Report of the Science and Art Department in the year 1870 is not yet published, we believe that the following chief results, taken from the Times, may be relied upon as accurate. The numbers who during 1870 have attended the schools, museums, and other institutions receiving Parliamentary aid, con. siderably exceed those of 1869 . There is a very large increase in the number of persons receiving instruction in science applicable to industry, which has risen from 24,865 in 1869 to 34,283 in 1870 , or upwards of 37 per cent. At the Royal School of Mines there were I' regular and 124 occasional students, at the Royal College of Chemistry I2I students, at the Royal School of Naval Architecture there were 40, and at the Metallurgical Laboratory 24. The evening lectures at the Royal School of Mines were attended by 2,574 artisans, school teachers, and others; and 243 science teachers attended the special courses of lectures provided for their instruction. At the Royal College of Science, Ireland, there were 17 associate or regular students and 2 I occasional students. The various courses of lectures delivered in connection with the department in Dublin were attended by I, 152 persons, and at the Evening Popular Lectures, which were given in the Edinburgh Museum of Science and Art during the session 1869.70 , there was an attendance of $I, 195$. The total number of persons who received direct instruction as studen's or by means of lectures in connection with the Science and Art Department in 1870 was upwards of 254,000 . showing an actual increase as compared with the number in the previous year of 67,000 , or nearly 36 per cent., and an increase in the rate of progress of 8 per cent; ; the numbers in 1869 having been nearly 28 per cent. higher than in 1868 . The museums and collections under the superintendence of the department in London, Dublin, and Edinburgh, have been visited during the past year by I, 847,929 persons, showing an increase of 49,087 on the number in 1869. As we have said before, it is impossible to over-estimate the importance of the work which is being done.

THE correspondence between the Royal Commission on Scientific Instruction and the Advancement of Science and the Science and Art Department on the subject of the transfer of the School of Mines to South Kensington, has been presented to Parliament.

THE assertion made by a contemporary relative to the endowment at University College of a De Morgan professorship of mathematics, has given rise to the statement by Prof. T. Hewitt Key, to the effect that he now withdraws the proposal, not merely because it is said by the family to be at variance with the expressed wishes of the deceased, but more because it has been hinted that he has been unworthily " using Prof. de Mor. gan's name against such expressed wishes for the emolument of the college." The endowment of a mathematical chair still remains as an object to which his best energies will be applied. 